\title{
Cost Analyses of Measures to Improve Residential Energy Ratings to 6 Stars - Playford North Development, South Australia.
}

Dr Martin Belusko and Mr Timothy O'Leary (University of South Australia)

\begin{abstract}
This paper reports the results of a study on the cost implications of achieving greater energy efficiency as measured by House Energy Rating (HER) 'stars' for new housing on a greenfield development in the northern suburbs of Adelaide. Twelve house designs typical of the housing options available from a number of builders engaged with this development were modeled using the $2^{\text {nd }}$ generation Building Code of Australia (BCA) accredited energy rating assessment tool AccuRate. Where the model predicted a rating below the minimum rating (6 star) proposed under the recently agreed Commonwealth of Australia, National Energy Efficiency strategy, the designs were modified in order to improve the rating to 6 stars using a combination of specification changes and energy efficient technology options. These changes or options were then priced at prevailing building suppliers and subcontractors retail cost levels in order that an average 'extra cost to 6 star' and range of indicative costs to achieve 6 star housing compliance could be articulated. The results revealed that standard and currently available technologies, such a reflective foil barriers, increased insulation and low emissivity 'e' type glazing provide a means to achieving 6 star ratings at a modest additional cost, i.e. 1-2\% of total construction and development costs.
\end{abstract}

Keywords: 6 Star costs, Energy rating, Sustainability, Sustainable housing, Energy efficiency

\section{Introduction}

In Australia, the regulation of energy efficiency of buildings is covered by a range of Commonwealth, State and Territory agencies. In April of 2009 specific measures to increase energy efficiency of buildings were set out in a Council of Australian Governments (COAG 2009) communiqué proposing :

- an increase in the stringency of energy efficiency for all classes of commercial buildings;

- mandatory disclosure of energy efficiency for all classes of commercial buildings;

- the phase-in of mandatory disclosure of residential building energy, greenhouse and water performance at the time of sale or lease, commencing with energy efficiency by 2011 ; and

- an increase in energy efficiency requirements for new residential buildings to six stars, or equivalent, nationally in the 2010 update of the Building Code of Australia with full implementation by all states by 2011.

The research presented in this paper aims at identifying additional capital costs associated with improving existing house designs to meet the new 6 star standard as per the latter of the four main proposals listed above. The focus is on the volume or 'project' home sector typical of modern suburban housing developments of reasonable scale (at least 30 plus allotments) where a number of builders compete on price and design features and where the blocks or allotments are developed on a phased basis over several or more years.

The paper demonstrates a case study approach for predicting the additional housing capital costs for achieving six star housing in a temperate climate and mature housing market such 
as is found in South Australia. An existing housing development, Playford North provided a source of typical housing designs where builders and suppliers could be queried on costs of energy efficiency measures and dwellings could be assessed for HER star ratings.

Housing energy efficiency as measured in 'stars' relates to the nationally adopted Home Energy Rating (HER) rating system and the use of software modeling as a route to verification for compliance with the energy efficiency requirements of Volume Two (residential class $1 \& 10$ ) of the BCA. This software simulation method allows for the modeling of energy performance of a house under both heating and cooling loads. The software used to assess the housing designs was the CSIRO AccuRate software version 1.4 which is accredited under the ratings protocol of the Australian Building Codes Board $(\mathrm{ABCB})$.

The modeling of improved building envelope thermal performance was limited in scope to typical temperate climate modifications around the elements of wall and roof insulation and glazing as has been shown in a number of recent studies by Constructive Concepts Pty (2009) and earlier by Burghardt (2008) to improve thermal performance in Australian housing and dwelling units. The focus on these elements is also supported by the prescriptive deemed to satisfy (DTS) measures for energy efficiency as adopted by the Australian Building Codes Board (2009). In relation to costing the design modifications the builders were queried as to likely 'upgrade' costs as well as costings by the authors using market information and publications. In a comparative cost benefit study of energy efficiency measures for Victorian housing, Energy Efficient Strategies (2002), data regarding costs of such products as insulation revealed two separate rate levels, i.e. a low rate applicable to volume builders and a higher rate applicable to non volume builders. The analysis revealed across a range of building products and various house improvement measures that volume builders generally enjoyed lower costs (in the order of 10\%).

\section{Playford North Housing Case Study - Design and Energy Efficiency Options}

The Playford North Urban Renewal Project is a major urban housing and infrastructure project located approximately 30 kilometres north of Adelaide, commenced in 2008 and set to continue for a 15 year anticipated development phase. Over this period it is anticipated that more than 5000 new houses will be constructed in a variety of phased land and allotment releases with involvement of many of the major volume residential builders operating in the South Australian market.

A number of Adelaide home building companies were approached in early 2009 to be part of this research study on a strictly confidential basis. From this initial approach a modest yet representative sample of 12 house designs and specifications suitable for construction were obtained from project home builders involved in the Playford development.

A typical specification for the style of housing is outlined in Table 1 below with a front elevation photo illustration in Figure 1:

Typical brick veneer house design has very low thermal mass caused by brick or concrete within the internal space, and can be essentially treated as lightweight (Athienitis and Santamouris, 2002). Recently, the level of air leakage in housing has improved, however unless it is measured it is not possible to significantly improve further, and default values are assumed. Internal loads cannot be controlled or easily determined, and generally, represent a small component of the total heating and cooling requirement.

Belusko, M and O'Leary, T (2010) 'Cost analyses of measures to improve residential energy ratings to 6 stars Playford North Development, South Australia', Australasian Journal of Construction Economics and Building, 10 (1/2) 36-47 


\begin{tabular}{|c|c|}
\hline Element & Construction for Base Design \\
\hline External Walls & Brick veneer + R1.5 insulation $+10 \mathrm{~mm}$ plasterboard \\
\hline $\begin{array}{l}\text { Windows/Ext. } \\
\text { Doors }\end{array}$ & $\begin{array}{l}\text { Aluminium framed single } 3 \mathrm{~mm} \text { clear float glass windows } \\
\text { Aluminium sliding door, single glazed } 5 \mathrm{~mm} \text { clear float flyscreens }\end{array}$ \\
\hline Internal Doors & Timber (solid) \\
\hline Floors & Ceramic tiles to wet areas, vinyl to kitchen areas, carpet to bedrooms \\
\hline Ceiling & 10mm plasterboard + R 3.0 Glasswool bulk insulation \\
\hline Roof & Concrete tiles - unsarked or Colorbond metal roof ( 25 deg pitch) \\
\hline Weatherstrip/ Seals & All windows, external doors and exhaust fans sealed/weatherstripped \\
\hline Air movement & Fans to main living room and bedrooms \\
\hline
\end{tabular}

Table 1 Typical base specification of Playford houses

Consequently, as far as minimising heating and cooling demand for brick veneer houses the primary focus is on reducing transmission and affecting solar load. Affecting solar loads relates to design decisions concerning the orientation of the building, window sizes and shading of windows. Transmission loads are reduced by applying various insulation technologies. Most brick veneer designs today consist of a large open plan living/dining/kitchen area with a number of contained bedrooms. The living zone represents those areas which are occupied during waking hours. The bedroom zone relates to areas occupied during sleeping hours. The living zone requires greater levels of comfort than bedroom zones and given that the living zone represents the majority of the house floor area, generally dominates the heating and cooling demand for a building. As a result effective design involves north facing windows in the living zone and ensuring all windows are shaded during summer.

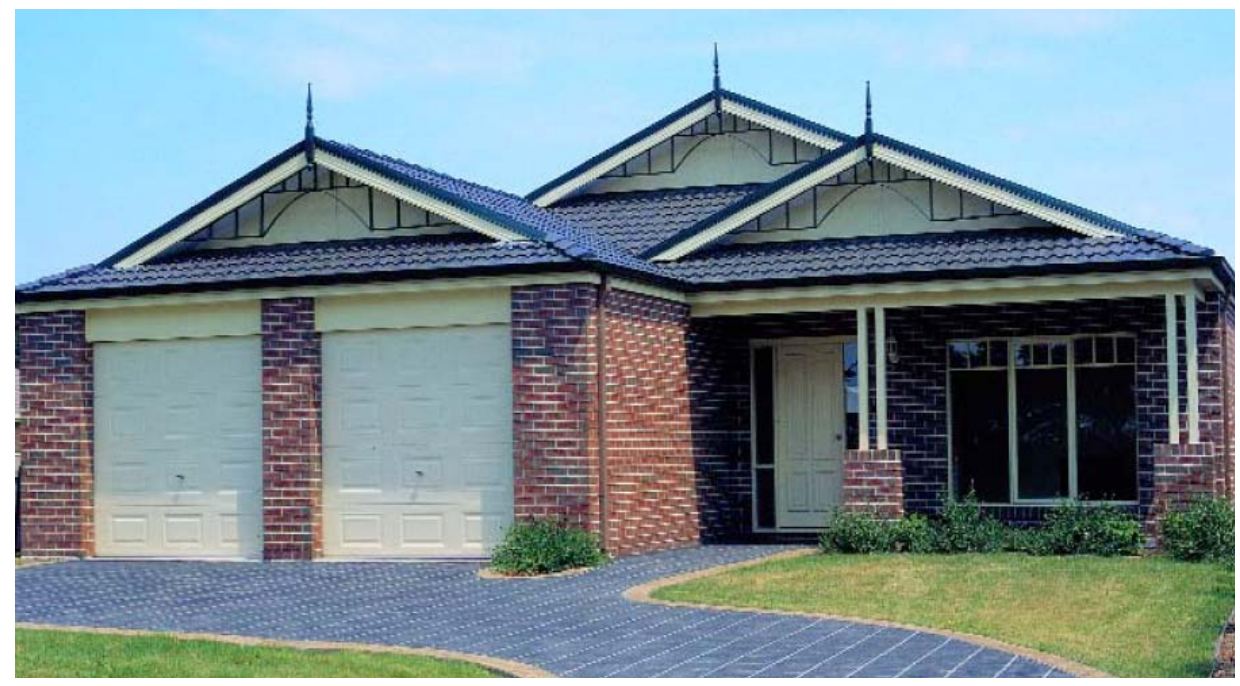

Figure 1 Playford housing - Photo of typical front elevation

Belusko, M and O'Leary, T (2010) 'Cost analyses of measures to improve residential energy ratings to 6 stars Playford North Development, South Australia', Australasian Journal of Construction Economics and Building, 10 (1/2) 36-47 


\section{Home Energy Rating - Calculation of the Star Rating, Heating and Cooling Loads}

The need for heating or cooling a house relates to the total effect of all heat flows in and out of the building. The sum of the total heat flow determines the internal temperature, and artificial heating or cooling is needed to reach comfort temperatures (ASHRAE, 2005). This is the method applied by AccuRate to determine the heating and cooling energy needed for a house design, from which the star rating is determined. An increase in star rating results in a lower energy demand in order to achieve assumed thermal comfort levels.. Once the data for a house has been entered the report features of the software can be used to generate two specific reports as below;

- A summary report listing the project, client and rating assessor details. The heating and cooling requirements (as measured in megajoules per $\mathrm{m}^{2}$ ) and most fundamentally a star rating in compliance with the BCA/Nathers protocol

- A more detailed Building Data Report which lists data on the construction elements for individual zones, sizes, openings etc.

The classification of houses situated in Playford North for climate data purposes under the National Home Energy rating system (NATHERS) is Climate zone 16 (Adelaide) and the relevant energy consumptions are respectively 125 and $96 \mathrm{MJ} / \mathrm{m}^{2}$ for 5 and 6 stars. Therefore, an increase from 5 to 6 stars represents a reduction of $23 \%$ in the energy demand of a house in the Adelaide climate zone. Whilst a target energy reduction of that magnitude might infer major building specification changes, housing design modifications around insulation and glazing and to a lesser extent shading and air movement devices are known to offer significant improvement to building thermal characteristics. Fricker (2002) in his study shows that the benefit of additional insulation levels is non linear and diminishes once high levels of insulation are 'standardised' into housing and a recent report by the Australian Window Association (2009) into the changes to a 6 star energy rating for residential buildings points to a requirement for high performance glazing as this insulation benefit reduces.

Smaller houses have a greater surface area compared to their floor area than larger houses. Because total heat flow through the building fabric is greatly influenced by the surface area, without a correction factor smaller houses of the same shape and materials will have higher energy loads per unit of floor area. This effect is exacerbated because window areas as a percentage of floor area are often relatively greater in small houses than in larger houses, and because heat flows through windows are generally the largest. In Regulation Mode, star ratings are to be based on energy loads that have been adjusted by an area adjustment factor (AAF). The size of the adjustment depends on the conditioned floor area and the climate zone. For Adelaide housing (Zone 5) the appropriate area adjustments used by the software in energy load calculations are:

$$
\frac{50 \mathrm{~m}^{2}}{1.2} \quad \frac{150 \mathrm{~m}^{2}}{0.3} \quad \frac{250 \mathrm{~m}^{2}}{-0.3} \quad \frac{350 \mathrm{~m}^{2}}{-0.8}
$$

\section{The AccuRate Results for the Case Study Houses}

When modelled in simulation mode the results of the base designs energy performance is listed in Table 2. Lot numbers refer to individual house designs unique to each allotment for which builders provided the required design information.

Belusko, M and O'Leary, T (2010) 'Cost analyses of measures to improve residential energy ratings to 6 stars Playford North Development, South Australia', Australasian Journal of Construction Economics and Building, 10 (1/2) 36-47 


\begin{tabular}{|r|c|c|c|c|c|}
\hline Lot & Base Star Rating & \multicolumn{2}{|c|}{ Unadjusted Load, $\mathbf{M J / \mathbf { m } ^ { 2 }}$} & $\begin{array}{c}\text { Ratio of Heating } \\
\text { to Total Load }\end{array}$ & $\begin{array}{c}\text { Floor Area, } \\
\mathbf{m}^{\mathbf{2}}\end{array}$ \\
\hline 16 & 4.9 & 78 & 63.8 & 0.55 & 175 \\
\hline 17 & 4.9 & 94.9 & 61 & 0.61 & 130 \\
\hline 23 & 5.8 & 58.8 & 53 & 0.53 & 142 \\
\hline 26 & 5.9 & 75.1 & 42.9 & 0.64 & 104 \\
\hline 13 & 5.4 & 53.4 & 63.5 & 0.46 & 170 \\
\hline 29 & 4.9 & 62.8 & 65.1 & 0.49 & 211 \\
\hline 184 & 4.9 & 59.5 & 77.4 & 0.43 & 188 \\
\hline 45 & 5.2 & 60 & 68.1 & 0.47 & 180 \\
\hline 901 & 5.1 & 70 & 68.5 & 0.51 & 167 \\
\hline 8 & 5.3 & 60.5 & 69.9 & 0.46 & 173 \\
\hline 902 & 5.4 & 51.7 & 62.5 & 0.45 & 224 \\
\hline 194 & 4.9 & 68.9 & 70.6 & 0.49 & 190 \\
\hline
\end{tabular}

Table 2 House star and thermal load information

Using the list of technology options listed in Tables 3 and 4, the star rating was increased to 6 stars for each house design. A condition of the upgrade in energy efficiency was that major changes to the floor plan, changes to window location or overall window and door sizes were deemed too great a divergence from an acceptable design solution for each lot. As a result the principal focus in increasing the star rating relates to technology options affecting the transmission heat flow through the house.

Lot 17 was the poorest design with a base star rating of 4.9 (Figure 1). As shown in Table 2 it had the highest heating load due to large southern windows and the northern windows shaded by the building preventing winter sun. As a result, in addition to adding the maximum levels of insulation in the building, the southern windows needed to be double glazed and the windows throughout the house required low emissivity glass.

Lot 26 was the best design with a base star rating of 5.9. Although the house required more energy to heat, per unit of floor area, than some other houses, due to its smaller floor area it was penalised less than other houses, and as a result achieved a higher rating. The house has minimum southern windows preventing heat loss, no eastern and western windows preventing the sun in the summer and northern windows providing for winter sun. To achieve 6 stars all that was required was foil in the roof.

Lot 184 was a typical design in that it applies the deemed to satisfy provisions of the BCA and achieves a star rating in the simulation method of 4.9. The building requires more cooling than heating and this is due to the large unshaded western windows in the living zone. Foil was added to the roof and walls, the internal wall was insulated and the roof insulation upgraded to 3.5. Low emissivity glass was applied to most of the glass doors/windows.

In addition to the development of the 6 star designs, the impact of the technology options was systematically investigated for each house design. Applying the list prescriptively, Tables 3 and 4 show the absolute and incremental impact on the star rating of the design, respectively.

In total, except for Lot 17, all other designs achieved 6 stars with the average house design reaching 6.4 stars. This result indicates that in general there is scope to reduce these measures, while maintaining the 6 star rating. Furthermore, although insulation options have been exhausted, there is scope to increase the star rating for those designs which achieve a significantly lower star rating. These measures include (in order of application):

Belusko, M and O'Leary, T (2010) 'Cost analyses of measures to improve residential energy ratings to 6 stars Playford North Development, South Australia', Australasian Journal of Construction Economics and Building, 10 (1/2) 36-47 
1. applying low E single glazing to all other windows/doors in the house

2. applying double glazing to the living zone windows/doors

3. applying double glazing to all windows/doors in the house

Based on the average increase, each technology option produces a meaningful increase in the star rating. The incremental increase that each technology option generates will be different depending on the order of application. Therefore, the average increase determined should only be used as a guide. Table 4 shows the average increase each technology option measure provides. Low $E$ single glazing is the most effective at 0.49 stars followed by the foil in roof, internal wall insulation and then the bulk insulation measures in the building envelope. This result reflects the fact that bulk insulation is already present in the house design and therefore any increase in the $\mathrm{R}$ rating will have less of an impact compared to glazing, where the original glazing has a very poor thermal resistance.

\begin{tabular}{|r|c|c|c|c|c|}
\hline \multirow{2}{*}{ Lot } & \multicolumn{4}{|c|}{ Updated Star Rating with Technology Option } \\
\cline { 2 - 6 } & Foil in roof & R2.5 ext walls & R4 roof & $\begin{array}{c}\text { R1.5 internal } \\
\text { walls }\end{array}$ & $\begin{array}{c}\text { Low E glass } \\
\text { in living } \\
\text { zone }\end{array}$ \\
\hline 16 & 5.2 & 5.4 & 5.6 & 5.9 & 6.4 \\
\hline 17 & 5.1 & 5.2 & 5.2 & 5.4 & 5.6 \\
\hline 23 & 6 & 6.1 & 6.3 & 6.4 & 6.7 \\
\hline 26 & 6.1 & 6.3 & 6.5 & 6.6 & 6.8 \\
\hline 13 & 5.7 & 5.8 & 5.9 & 5.9 & 6.3 \\
\hline 29 & 5.2 & 5.4 & 5.4 & 5.4 & 6.1 \\
\hline 184 & 5.2 & 5.3 & 5.4 & 5.6 & 6.2 \\
\hline 45 & 5.4 & 5.6 & 5.8 & 6 & 6.6 \\
\hline 901 & 5.3 & 5.4 & 5.6 & 6 & 6.6 \\
\hline 8 & 5.5 & 5.6 & 5.6 & 5.8 & 6.5 \\
\hline 194 & 5.7 & 5.8 & 5.8 & 6.1 & 6.6 \\
\hline
\end{tabular}

Table 3 Cumulative star rating impact of each technology measure for each lot

\begin{tabular}{|c|c|c|c|c|c|}
\hline \multirow{2}{*}{ Lot } & \multicolumn{4}{|c|}{ Star Rating Increase with Technology Option } \\
\cline { 2 - 6 } & Foil in roof & R2.5 ext walls & R4 roof & $\begin{array}{c}\text { R1.5 internal } \\
\text { walls }\end{array}$ & $\begin{array}{c}\text { Low E glass } \\
\text { in living } \\
\text { zone }\end{array}$ \\
\hline 16 & 0.3 & 0.2 & 0.2 & 0.3 & 0.5 \\
\hline 17 & 0.2 & 0.1 & 0 & 0.2 & 0.2 \\
\hline 23 & 0.2 & 0.1 & 0.2 & 0.1 & 0.3 \\
\hline 26 & 0.2 & 0.2 & 0.2 & 0.1 & 0.2 \\
\hline 13 & 0.3 & 0.1 & 0.1 & 0 & 0.4 \\
\hline 29 & 0.3 & 0.2 & 0 & 0 & 0.7 \\
\hline 184 & 0.3 & 0.1 & 0.1 & 0.2 & 0.6 \\
\hline 45 & 0.2 & 0.2 & 0.2 & 0.2 & 0.6 \\
\hline 901 & 0.2 & 0.1 & 0.2 & 0.4 & 0.6 \\
\hline 8 & 0.2 & 0.1 & 0 & 0.2 & 0.7 \\
\hline 902 & 0.3 & 0.1 & 0 & 0.3 & 0.5 \\
\hline 194 & 0.2 & 0 & 0.1 & 0.2 & 0.6 \\
\hline Average & $\mathbf{0 . 2 4}$ & $\mathbf{0 . 1 3}$ & $\mathbf{0 . 1 1}$ & $\mathbf{0 . 1 8}$ & $\mathbf{0 . 4 9}$ \\
\hline
\end{tabular}

Table 4 Incremental increase of star rating (rounded to one decimal) by impact of each technology measure for each lot

Belusko, M and O'Leary, T (2010) 'Cost analyses of measures to improve residential energy ratings to 6 stars Playford North Development, South Australia', Australasian Journal of Construction Economics and Building, 10 (1/2) $36-47$ 
The performance of the foil reflects the increased impact of the cooling demand on higher star rated homes, and is an important measure for higher star rated houses. Internal wall insulation isolates the living zone from the rest of the house and effectively reduces the conditioned area.

\section{Cost Analysis - Cost per star, Cost per technology option}

Costs were determined based on retail costs not including GST. The actual cost increases for each lot relates to the specific design choices and combinations of technology options around insulation and glazing. These design choices were made in order to minimise cost. Table 5 below shows these upgrade costs.

\begin{tabular}{|l|c|c|c|c|}
\hline \multirow{2}{*}{ Lot } & \multirow{2}{*}{ Base Stars } & $\begin{array}{c}\text { Estimated } \\
\text { Upgrade Cost }\end{array}$ & \multicolumn{2}{c|}{ Normalised Cost } \\
\cline { 4 - 5 } & & 3958 & 3872 & Cotal \\
\hline 16 & 4.9 & 4801 & 6321 & 5520 \\
\hline 17 improved & 4.9 & 433 & 521 & 2607 \\
\hline 23 & 5.8 & 134 & 220 & 2199 \\
\hline 26 & 5.9 & 863 & 869 & 1448 \\
\hline 13 & 5.4 & 7880 & 6392 & 5811 \\
\hline 29 & 4.9 & 5516 & 5022 & 4566 \\
\hline 184 & 4.9 & 2678 & 2546 & 3183 \\
\hline 45 & 5.2 & 1422 & 1457 & 1619 \\
\hline 901 & 5.1 & 2243 & 2219 & 3170 \\
\hline 8 & 5.3 & 1469 & 1122 & 1870 \\
\hline 902 & 5.4 & 6404 & 5770 & 5245 \\
\hline 194 & 4.9 & 6590 & 8677 & 7888 \\
\hline 17 as provided & 4.9 & 3150 & 3028 & 3415 \\
\hline Average & 5.2 & & & \\
\hline
\end{tabular}

Table 5 Cost estimates to upgrade existing designs to 6 stars (\$AUS June 2009 prices)

Overall, the range of costs was large, with a minimum of $\$ 134$ and a maximum of $\$ 7880$, with the average being $\$ 3150$. This range is significant and reflects design choices made which affected the need for a glazing solution. Where a glazing solution was not required cost increases were negligible. Two options are provided for Lot 17, the as provided value represents what was advised to builders, however, this was able to be significantly improved, and this value is presented. To compare each house correctly, the costs were normalised to the average floor area of $171 \mathrm{~m}^{2}$, and the cost per star was determined.

For example, Lot 23 has a floor area of $142 \mathrm{~m}^{2}$ (see Table 2).

$\begin{array}{llll}\text { Upgrade cost/floor area } & \$ 433 / 142 \mathrm{~m}^{2} & =\$ 3.05 / \mathrm{m}^{2} \\ \text { Normalised to Average size house } & 171 \mathrm{~m}^{2} \times \$ 3.05 & =\$ 521\end{array}$

For the 12 houses in the study the average cost per star is $\$ 3415+/-46 \%$. All average values only consider the improved arrangement for Lot 17.

The study assumes that a cost minimisation approach is available to the builder and that in the absence of being able to make specific design choices, the cost of upgrading, applying the measures listed in Tables 3 and 4 can be calculated (Table 6). This costing exercise is based on applying the list of measures in full irrespective of whether it achieves a higher star rating than six. Based on the average of each measure the highest cost is clearly the glazing solution followed by foil, internal wall insulation and with external wall and roof

Belusko, M and O'Leary, T (2010) 'Cost analyses of measures to improve residential energy ratings to 6 stars Playford North Development, South Australia', Australasian Journal of Construction Economics and Building, 10 (1/2) $36-47$ 
insulation being the least costly. This is expected as currently external walls and roof are already insulated, and therefore the cost is only the cost of upgrading.

\begin{tabular}{|r|c|c|c|c|c|}
\hline \multirow{2}{*}{ Lot } & \multicolumn{5}{|c|}{ Cost Increase of Technology Option, \$AUD } \\
\cline { 2 - 6 } & Foil in roof & $\begin{array}{c}\text { R2.5 ext } \\
\text { walls }\end{array}$ & R4 roof & $\begin{array}{c}\text { R1.5 internal } \\
\text { walls }\end{array}$ & $\begin{array}{c}\text { Low E glass } \\
\text { in living zone }\end{array}$ \\
\hline 16 & 526 & 213 & 168 & 478 & 3322 \\
\hline 17 & 358 & 190 & 53 & 389 & 2458 \\
\hline 23 & 433 & 77 & 136 & 422 & 3309 \\
\hline 26 & 320 & 204 & 100 & 251 & 3225 \\
\hline 13 & 518 & 87 & 163 & 539 & 4264 \\
\hline 29 & 743 & 286 & 202 & 520 & 4767 \\
\hline 184 & 578 & 276 & 180 & 498 & 4720 \\
\hline 45 & 550 & 244 & 173 & 638 & 4114 \\
\hline 901 & 460 & 239 & 160 & 582 & 4318 \\
\hline 8 & 475 & 77 & 71 & 558 & 3873 \\
\hline 902 & 618 & 101 & 92 & 750 & 4543 \\
\hline 194 & 530 & 88 & 78 & 774 & 4935 \\
\hline Average & 509 & $\mathbf{1 7 3}$ & $\mathbf{1 3 1}$ & $\mathbf{5 3 3}$ & $\mathbf{3 9 8 7}$ \\
\hline
\end{tabular}

Table 6 Cost increase of each measure for each lot

Table 7 presents the total cost of applying the measures with the average being $\$ 5334$. The average total based on normalising the cost to the average floor area of $171 \mathrm{~m}^{2}$ was $\$ 5377$ $+/-12 \%$. This cost is significantly higher than the actual upgrade cost presented in Table 5. This difference represents the cost minimisation process. Where a process of optimisation can be applied in the modelling, an average cost saving of $\$ 1962$ or average rate of $\$ 11.47 / \mathrm{m}^{2}$ GFA can be achieved.

This variation of the average total cost of applying the measures in Table 7 represents the different choices in window/sliding door area and living room areas which will affect the cost. Generally the cost variation is small for applying all the measures. As shown in Table 3 the application of these measures delivers varying increases in star rating often well above 6 stars.

Table 7 also presents the cost of a 1 star increase for each lot with the average being $\$ 4921$ $+/-27 \%$. The variation shows the impact of the design and relates to the base star rating. Although this represents the true cost of going from a 5 to 6 star design in practice it will depend on whether designers are able to implement a portion of a measure. For example, applying R3.5 in the roof as opposed to R4, or applying low emissivity glass to some of the glass doors and windows in the living zone.

Figure 2 presents the average normalised cost of each measure together with the star increase this measure delivers. A description of the measure is presented in Table 8. The figure shows that the trends of cost and star increase are essentially identical with the foil and internal wall insulation measure providing higher star increases at higher costs than external wall and roof insulation. What the graph also highlights is that once insulation solutions are exhausted a significant increase in cost occurs with the implementation of the glazing solution. This cost is particularly relevant to poor house designs, as glazing solutions are the only alternative technology option to achieving higher star ratings.

Belusko, M and O'Leary, T (2010) 'Cost analyses of measures to improve residential energy ratings to 6 stars Playford North Development, South Australia', Australasian Journal of Construction Economics and Building, 10 (1/2) 36-47 


\begin{tabular}{|r|c|c|c|}
\hline \multirow{2}{*}{ Lot } & Total Cost & \multicolumn{2}{|c|}{ Normalised Cost } \\
\cline { 2 - 4 } & & Total & Cost/star \\
\hline 16 & 4708 & 4605 & 3070 \\
\hline 17 & 3448 & 4540 & 6486 \\
\hline 23 & 4377 & 5276 & 5862 \\
\hline 13 & 4100 & 6747 & 7497 \\
\hline 29 & 5571 & 5609 & 6233 \\
\hline 184 & 6518 & 5287 & 4406 \\
\hline 45 & 6251 & 5692 & 4378 \\
\hline 801 & 5718 & 5438 & 3884 \\
\hline 902 & 5759 & 5902 & 3935 \\
\hline 194 & 5054 & 5000 & 4167 \\
\hline Average & 6103 & 4663 & 3886 \\
\hline
\end{tabular}

Table 7 Total cost and total normalised cost to a $171 \mathrm{~m}^{2}$ floor area

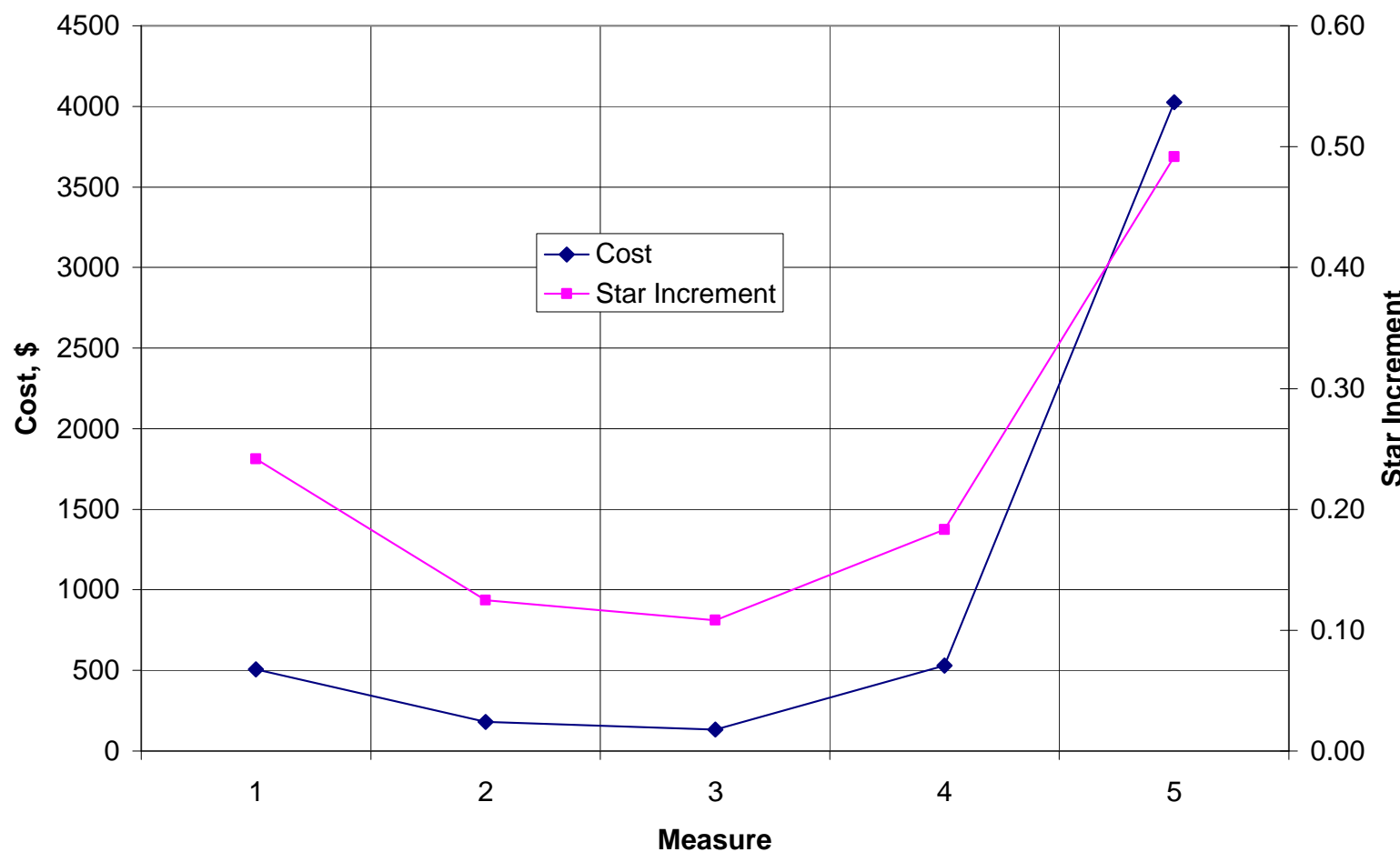

Figure 2 Normalised cost and star rating increment of each measure, as defined in Table 8, for a $171 \mathrm{~m} 2$ floor area house

Table 8 presents the star increase each measure delivers per $\$ 1000$ of cost. What it shows is that increasing external wall and roof insulation are the most cost effective measures followed by adding foil and internal wall insulation and finally the glazing solution. This result shows that although internal wall insulation and foil are of low cost, they are an addition as opposed to an upgrade and therefore are less cost effective than external wall and roof insulation measures. The glazing solution is significantly less cost effective than the insulation solutions. 


\begin{tabular}{|c|l|c|}
\hline 1 & Foil in roof & 0.48 \\
\hline 2 & R2.5 ext walls & 0.69 \\
\hline 3 & R4 roof & 0.82 \\
\hline 4 & R1.5 internal walls & 0.35 \\
\hline 5 & Low E glass in living zone & 0.12 \\
\hline
\end{tabular}

Table 8 Star rating increase per $\$ 1000$ for each measure in Table 4

A retail market based approach was used in costing the various material and technology combinations modeled to improve the star rating. Suppliers and subcontractors in the South Australian home building market were willing to provide indicative supply prices at a retail price i.e. without any mark downs that can often be negotiated by volume purchases or companies using long term customer relationships as price bargaining leverage. Therefore it could be said the figures used in the analysis may slightly overstate the increased cost effect of additional measures or higher specification in the houses variations.

Appendix A (Tables A.1 and A.2) presents the list prices as provided by company A for various batt sizes and foils, and companies $C, D$ and $F$ for windows with a discount incorporated. A survey of prices in a major hardware store showed a discount of $46 \%$ for batts and a discount of $62 \%$ for foils (ignoring GST). These are discounts from normal retail prices and it was explained by Company $A$, that volume home builders would achieve an additional $10 \%$ discount. Appendix $\mathrm{A}$ also provides installation prices at prevailing labour rates that are consistent with current construction cost data publications such as Rawlinsons (2009)

\section{Conclusions}

With moves towards the 6 star energy efficiency rating for houses, the cost implications need to be analysed. The study of Adelaide houses shows a range of indicative costs at an average of cost increase to achieve 6 stars of some $\$ 3,150$. Given average house and land package of $\$ 290,000$ this represents a low order of cost increase for a housing consumer with anticipated benefits of greater thermal performance built into the house.

Integrated with this issue is the development of an effective methodology by which designers can readily achieve 6 stars. A five step approach was investigated which involves applying various insulation options and then applying the lowest cost glazing option. Applied as a guide this was used on 12 house designs upgrading the designs to 6 stars, through an optimisation process aimed at minimising cost. The variation in the original base star rating was a single star rating, which reflected the impact of the design modification. Whilst the average cost increase to achieve 6 stars for all designs was $\$ 3150$, a significant range in cost increase occurred, from $\$ 134$ to $\$ 7880$ due to the required application of various technology options. The principal cost increase is the application of the new glazing solution, low emissivity glass.

The most cost effective measures was increasing bulk insulation in the external walls and roof, however this was due to the associated costs only being an upgrade cost. Applying reflective foil in the roof together with internal wall insulation was the next most cost effective option achieving 0.24 and 0.18 increases in stars. The most effective increase in star rating was the glazing option increasing the star rating by an average of 0.49 .

In this study basic design modification principles were identified which can mitigate the costs associated with upgrading to 6 stars. Consequently, together with the technology options currently available, the cost increase to 6 stars can be described as modest or minor.

Belusko, M and O'Leary, T (2010) 'Cost analyses of measures to improve residential energy ratings to 6 stars Playford North Development, South Australia', Australasian Journal of Construction Economics and Building, 10 (1/2) 36-47 


\section{References}

Australian Building Codes Board (ABCB) (2009) Supporting Commentary on the Proposals to Amend the Energy Efficiency Provisions in the Building Code of Australia Volume 2 for 2010, ABCB, Canberra, ACT

ASHRAE (2005) ASHRAE Handbook - Fundamentals, American Society of Heating, Refrigerating and Air-Conditioning Engineers Inc., Atlanta, USA

Australian Window Association (AWA) (2009) Industry Capacity/Capability Study, Australian Window Association, Gordon, New South Wales

Athienitis A. and Santamouris. M. (2002) Thermal Analysis and Design of Passive Solar Buildings, James and James, London

Ambrose, M. Delsante, A. Johnson, D. and Tucker, S.N. (2004) Energy Efficiency Uptake Within the Project House Building Industry, CSIRO, Canberra, ACT

Burghardt, G. (2008) Study of the Thermal Performance of Class 2 Multiple Unit Dwellings using Accurate House Energy Rating Software, report for the Australian Building Codes Board, Nov. Canberra, ACT

Constructive Concepts (2009) Building Improvements To Raise House Energy Ratings From 5.0 Stars, Overview of Systematic AccuRate Modelling for the Australian Building Codes Board, Tony Isaacs Consulting, Australian Building Codes Board, Canberra, ACT

Council of Australian Governments (COAG), 2009 Communiqué, Hobart April 2009 National Strategy on Energy Efficiency, Canberra ACT

Energy Efficient Strategies, (2002) Comparative Cost Benefit Study of Energy Efficiency Measures for Class 1 Buildings and High Rise Apartments, Report for the Sustainable Energy Authority of Victoria, Melbourne, Australia

Fricker, J (2002) 'The Diminishing Benefit of Extra Home Insulation', viewed at http://fricker.net.au accessed 09/06/09

Rawlinsons (2009) Australian Construction Handbook 2009, Rawlhouse Publishing Pty Ltd. Perth, Western Australia

\section{Appendix A}

\begin{tabular}{|l|l|}
\hline Insulation Product & $\mathbf{\$ / \mathbf { m } ^ { 2 }}$ \\
\hline R2 bulk insulation & 4.29 \\
\hline R2.5 bulk insulation & 4.87 \\
\hline R3 bulk insulation & 5.07 \\
\hline R3.5 bulk insulation & 5.62 \\
\hline R4 bulk insulation & 6.03 \\
\hline R1.5 bulk insulation & 3.19 \\
\hline Single sided reflective foil & 1.00 \\
\hline Double sided reflective foil & 1.05 \\
\hline Installation cost & 1.50 \\
\hline
\end{tabular}

Table A.1: Retail prices for insulation (non GST)

Belusko, M and O'Leary, T (2010) 'Cost analyses of measures to improve residential energy ratings to 6 stars Playford North Development, South Australia', Australasian Journal of Construction Economics and Building, 10 (1/2) 36-47 


\begin{tabular}{|l|c|l|}
\hline \multicolumn{1}{|c|}{ Window } & Company & $\$ \mathbf{m}^{2}$ \\
\hline Standard clear single glazed window & C & 223 \\
\hline Standard clear single glazed door & C & 278 \\
\hline Standard clear single glazed window & D & 118 \\
\hline Standard clear single glazed door & D & 168 \\
\hline Low E single glazed window & C & 426 \\
\hline Low E single glazed door & C & 466 \\
\hline Standard double glazed window & D & 307 \\
\hline Standard double glazed door & D & 526 \\
\hline High performance double glazed window & F & 450 \\
\hline High performance double glazed door & F & 940 \\
\hline
\end{tabular}

Table A.2: Retail prices for windows (non GST) 